\title{
Antenatal thoracoamniotic shunting in congenital cystic adenomatoid malformation
}

\author{
Terry Cullen, ${ }^{1}$ Clare Tower, ${ }^{2}$ Kristin Tanney $^{1}$
}

${ }^{1}$ Neonatal Intensive Care Unit, Central Manchester University Hospitals NHS Foundation Trust, Manchester, UK

${ }^{2}$ Fetal Medicine Unit, Central Manchester University Hospitals NHS Foundation Trust, Manchester, UK

Correspondence to Dr Terry Cullen, tdcullen@hotmail.co.uk

Accepted 2 June 2017
CrossMark

To cite: Cullen T, Tower $C$, Tanney K. BMJ Case Rep Published Online First: [please include Day Month Year]. doi:10.1136/bcr-2016217940

\section{DESCRIPTION}

This case report describes a baby who was diagnosed antenatally with a significant left-sided congenital cystic adenomatoid malformation.

Following diagnosis of a fluid-filled, macrocystic structure on the left side of the chest, the mother was referred at 27 weeks' gestation to her regional fetal medicine unit for assessment and ongoing management. Fetal MRI demonstrated a cyst measuring $6.7 \mathrm{~mm} \times 4.3 \mathrm{~mm}$, associated with mediastinal shift and affecting cardiac contractility. Scalp oedema and ascites noted at this time indicated evolving fetal hydrops.

At 28 weeks, thoracoamniotic shunt was inserted to drain the lesion. By 29 weeks, the cyst had decreased in size, now $5.1 \mathrm{~mm} \times 3.4 \mathrm{~mm}$. Cardiac function, oedema and ascites had all improved.

Subsequent scans showed that the shunt, initially placed successfully, had completely migrated into the cyst. Further drainage was completed at $37+3$ weeks, with $90 \mathrm{~mL}$ of fluid needle aspirated.

Labour was induced, and baby was delivered at $37+4$ weeks. He was born in good condition, needing no resuscitation, but was electively intubated and ventilated in view of his history.

Chest X-ray on admission to the neonatal intensive care unit (figure 1) showed evidence of the large left-sided cystic structure with migrated thoracoamniotic shunt in-situ.

Baby underwent a left lower lobectomy on day 3 of life. Despite an initially stormy postoperative period, he extubated successfully and was gradually weaned off respiratory support. Postnatal echocardiogram was normal.

Baby was discharged home at 6 weeks old on low-flow oxygen. By 6 month follow-up, he was off oxygen and demand feeding, with normal growth and development.

Contributors TC drafted the manuscript. CT provided the antenatal history and shunt. KT oversaw the manuscript submission and proof-reading.

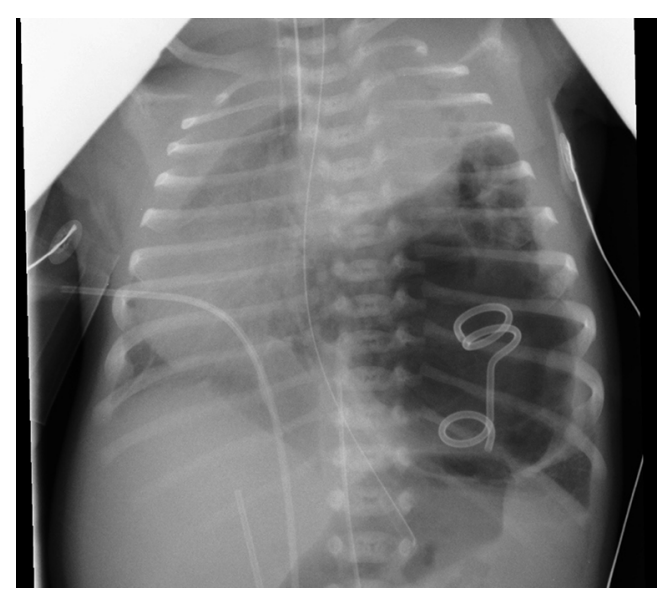

Figure 1 Taken shortly after birth, this X-ray demonstrates the large left-sided congenital cystic adenomatoid malformation, with migrated thoracoamniotic shunt in-situ.

\section{Learning points}

- This baby's perioperative chest X-ray (figure 1) provides an interesting image, combining evidence of his congenital cystic adenomatoid malformation and the migrated thoracoamniotic shunt.

- Baby's positive outcome demonstrates the potential success of novel and timely antenatal interventions.

\section{Competing interests None declared.}

Patient consent Consent obtained from Guardian.

Provenance and peer review Not commissioned; externally peer reviewed.

(C) BMJ Publishing Group Ltd (unless otherwise stated in the text of the article) 2017. All rights reserved. No commercial use is permitted unless otherwise expressly granted.

Copyright 2017 BMJ Publishing Group. All rights reserved. For permission to reuse any of this content visit http://group.bmj.com/group/rights-licensing/permissions.

BMJ Case Report Fellows may re-use this article for personal use and teaching without any further permission.

Become a Fellow of BMJ Case Reports today and you can:

- Submit as many cases as you like

- Enjoy fast sympathetic peer review and rapid publication of accepted articles

- Access all the published articles

- Re-use any of the published material for personal use and teaching without further permission

For information on Institutional Fellowships contact consortiasales@bmjgroup.com

Visit casereports.bmj.com for more articles like this and to become a Fellow 